\title{
Comparative Analysis of Conventional and Islamic Banking: The Case of Bakhtar Bank Transforming into Islamic Bank of Afghanistan
}

\author{
Erdal ARSLAN $^{*} \quad$ Ali BORA** ${ }^{* *}$ Abdul Hasib AMANAT***
}

\begin{abstract}
This article examines the financial performance of the Islamic Bank of Afghanistan after it transformed its form of banking from traditional Bakhtar Bank to Islamic Bank. in order to know whether or not there are significant differences in banks' financial performance. We conducted the financial ratio analysis on audited financial statements of the bank from 2009 to 2019.

As a result of the financial ratio analysis, we found that the bank's financial performance has significantly improved from different perspectives namely return on assets, return on equities, liquidity, solvency, and leverage ratios have respectively increased by 0.005, 0.09, 1.69, 0.009, and 8.3 percent. In conclusion, the financial performance of Islamic bank of Afghanistan is considered superior compared to Bakhtar banks' performance and Islamic Banking is considered favorable and successful in Afghanistan compared to Traditional banking.
\end{abstract}

Key Words: Islamic Bank of Afghanistan, Traditional Bank, Islamic Bank, Financial Ratio Analysis.

JEL Classification: $G 21, G 23, G 24$

\section{Geleneksel ve İslami Bankacılığın Karşılaştırmalı Analizi: Bakhtar Bank'm Islamic Bank of Afghanistan'a (Afganistan İslam Bankası’na) Dönüşmesi Örneği}

\section{$\ddot{O} Z$}

Bu çalışma, Afganistan İslami Bankası'nın mevcut durumunun geleneksel bankacılık yaptı̆̆ ve Bahtar Bank olarak adlandirıldiğg önceki dönemi ile finansal performans açısından karşılaştırmalı olarak incelemekte ve Bahtar Bank'in İslami bir bankaya dönüştükten sonra finansal performansinda önemli farklılıklar olup olmadı̆̆ını ortaya koymaktadır. Bu çalışmada, Bankanın 2009-2019 dönemi finansal tablolar kullanılarak finansal oran analizi yönetimiyle incelenmiştir.

Finansal oran analizi sonucunda, bankanin finansal performansının farklı açılardan önemli ölçüde gelişstiğini, varlıkların getirisi, özkaynakların getirisi, likidite, ödeme gücü ve kaldıraç oranlarının sirasıyla yüzde 0,005, 0,09, 1,69, 0,009 ve 8.3 arttı̆̆ belirlenmiştir. Çalışma sonucunda, Islamic Bank of Afghanistan (Afganistan İslam Bankasi)'in finansal performansinın geleneksel bankacılık yaptığı ve Bakhtar Bank olarak adlandırıldı̆̆ önceki dönem performansina göre daha yüksek olduğu ve Afganistan'da İslami Bankacılığın geleneksel bankacılığa kıyasla olumlu ve başarılı olduğu sonucuna ulaşılmışıtır.

\footnotetext{
*Associate Professor, Dr., Selcuk University, Department of Economics, Konya, Turkey, erdalarslan@selcuk.edu.tr, ORCID Bilgisi: 0000-0003-4892-2963.

${ }^{* *}$ Assistant Professor Dr., Selcuk University, Vocational School of Social Sciences, Department of FinanceBanking and Insurance Konya, Turkey, ali.bora@selcuk.edu.tr, ORCID Bilgisi: 0000-0002-1766-0123

${ }^{* * *}$ Master's Student, Selcuk University, Department of Economics, Konya, hasib.amanat@gmail.com, ORCID Bilgisi: 0000-0002-2679-3075
} 
Erdal Arslan \& Ali Bora \& Abdul Hasib Amanat / Comparative Analysis of Conventional and Islamic Banking:

The Case of Bakhtar Bank Transforming into Islamic Bank of Afghanistan

Anahtar Kelimeler: Afganistan İslami Bankası, Geleneksel Banka, İslami Banka, Parasal Oran Analizi.

JEL Sinıflandırması: $G 21$, G23, G24

\section{INTRODUCTION}

In this chapter, we have discussed the importance or potential needs of the Islamic banking system, its' history, and the rapid growth of this system across the globe. What are the needs of this banking system in Afghanistan? Will this banking system attract almost $90 \%$ of the Afghanistan population that does not use banking services to start using banking services?

The inclusive economy of the world is growing in an extraordinary degree and there's a huge difference in wealth distribution between the society so far this issue is leading to negative social and economic impacts in the society, for instance, it eliminates trust, create barriers to social mobility for generations, increase wars and crimes in the society. Therefore, the warm discussions about how to minimize the unequal distribution of wealth and its negative impacts on society and how to promote shared prosperity in societies are continuing (International Business \& Economics Research Journal, 2015).

(OXFAM International, 2014, pp. 1-20) has reported below facts related to our topic, we could understand how inadequate world wealth is distributed among the world population;

- Nearly $1 \%$ of the world's population controls $50 \%$ of the world's wealth.

- The amount of that $1 \%$ of the population's wealth is equal to 110 trillion dollars which is equal to 65 times of the bottom $50 \%$ world's population.

- 7 out of 10 people are living in those countries where wealth distribution unequally increased during the last 30 years.

- $1 \%$ of rich people in the United State has occupied $95 \%$ of wealth after the 2009 financial crisis, while the remaining percentage get poorer.

The development community's worried regarding rising inequality in the sharing of wealth that led them to realize the importance of the equal distribution of wealth. Though, there are different ways of achieving this aim.

Islamic economics and finance have been a good solution and option for above mentioned developing problems. This factor considerably comprehended the need of Islamic economics and Islamic banking. Islamic economics emphasizes on promoting equal distribution of wealth and suggesting policies and tools for the intervention of policymakers to enhance Islamic economics and Islamic banking to minimize the inequality in wealth distribution and remove extreme poverty in the world (International Business \& Economics Research Journal, 2015).

"Today Islamic Finance is a $\$ 2.2$ trillion industry with hundreds of specialized institutions located in more than 60 countries. Islamic banks are by far the biggest players in the Islamic finance industry and account for $\$ 1.5$ trillion in assets. According to a 2017 Reuters report, Islamic bank assets should reach \$2.7 trillion while total sharia-compliant assets are expected to grow to $\$ 3.5$ trillion by 
2021. The IMF plans to add Islamic finance to its financial sector assessments beginning in 2019. Islamic finance only represents about $1 \%$ of global financial assets but with a 10\%-12\% annual growth rate, it is expanding more quickly than conventional finance. In some geographies like the Gulf or Sub-Saharan Africa, Islamic banks now compete directly with Western banks to attract Muslim clients" (Domat, 2019).

With the evolution of Islam in the $8^{\text {th }}$ Century, Islamic Economic and Finance has started to operate in the Islamic world from Morocco to China in all vast territories of Islamic countries. The Islamic economic records are scripted in the Holy Quran and Sunna books. Furthermore, with the expansion of Islam the trading between Muslim countries has increased around the $10^{\text {th }}$ century which has expressed the contribution of Muslim traders in Banking operations. Which has resulted in the motivation of the development of the finance sector in the Italian peninsula at the end of the Middle Ages (Chachi A. , 2005, pp. 132-145). This engagement in the past appears to be an essential step to know the details of Islamic finance. This is also common with other religions, for instance, the question of the exclusion of usury, after the Middle Ages, Islamic finance stayed on the sidelines of the capitalist financial development. Nonetheless, for the past 30 years, Islamic finance has been evolving again, based on educations bequeathed by a still-living practice and arises as a substitute to the conventional banking and financial system (International Business \& Economics Research Journal, 2015).

The attractiveness of the Islamic banking system is not only in Muslims or Muslim countries but in many non-Muslim communities and countries and they are customers of this banking system. It is reported that in 75 countries there are almost 300 Islamic financial institutions by the State bank of Pakistan ( State Bank of Pakistan Islamic Banking Department, 2013, p. 2).

The banking sector is playing an important role in Afghanistan economic development and Islamic Banking is considered and expected to be efficient in absorbing nations trust in the Banking sector because $99 \%$ of Afghanistan population are Muslims and currently only $7.5 \%$ of the population is dealing with banking sector due to the reason that interest-based banking is forbidden in Islam, the Islamic banking system is based on Sharia law and principles, Sharia law does not allow receiving and payment of "Riba" interest and excessive ambiguity, gambling or financing those activities which are harmful to society (Mastoor, 2014, pp. 2-10).

If we have a closer look to the definition of Bank, it is an institution which is involved in borrowing from those who have an extra amount of money and lend to those who need that amount for investing for the sake of profit/interest these activities lead to economic development and growth (Pettinger, 2017).

On the other hand, Islamic Banking is a banking system that is performing its activities with the respect to Islamic law or Sharia, and it is a key fact that Islamic law is not allowing receiving or payment of usury or interest and Haram activities like gambling, arms manufacturing and Alcohol production (Domat, 2019). 
Then the question arises that does Islamic Banks make a profit? In this article, we would find out the financial performance of Bakhtar Bank before and after its conversion to the Islamic Bank of Afghanistan. Is the Islamic Banking system a total loss for its shareholders or it is profitable?

\section{RESEARCH OBJECTIVE:}

The objective of this research paper is to comparatively examine the financial performance of the Bakhtar Bank after conversion to Islamic Bank of Afghanistan to find out the significant changes in the financial performance of the bank or to study the impact of conversion from the traditional banking system to the Islamic banking system and its outcomes.

\section{HYPOTHESIS:}

H1: If the performance of Bakhtar Bank is superior since it has converted to the Islamic Bank of Afghanistan.

$\mathrm{H} 0$ : If the performance of Bakhtar Bank is inferior since it has converted to the Islamic Bank of Afghanistan.

\section{LITERATURE REVIEW:}

We have studied literature regarding our research article and the relevant pieces of literature are divided into two kinds for the purpose of providing a comprehensive image of Afghanistan Islamic banking and the global cases of Islamic banks analysis thus we explained it in the theoretical literature and empirical literature, firstly we will elaborate theoretical literature underneath;

\section{A. Islamic Banking in Afghanistan and Islamic Bank of Afghanistan:}

The banking sector is playing an important role in Afghanistan economic development and Islamic Banking is considered and expected to be efficient in absorbing nations trust in the Banking sector because 99\% of Afghanistan population are Muslims and currently only $7.5 \%$ of the population is dealing with banking sector although banking facilities are focused in only a few cities for instance $75 \%$ of loans are given in Kabul city, therefore, it's expected that Islamic banking system will have a huge influence on the people across the country to deposit their amounts of cash in the bank and take loans. Due to civil war in the country, the banking sector was deactivated for a decade, fortunately after 2001 with the help of the International community once again Afghanistan banking system had rebuilt based on updated technology and international banking standards. Before 2001 there were 3 inactive state banks but after 2001 there were around 18 banks and 400 Branches of domestic and foreign banks in Afghanistan (Mastoor, 2014, pp. 2-10).

The fact that $7.5 \%$ of 30 million people of Afghanistan practice interestbased banking sector services and Da Afghanistan Bank (Central Bank of Afghanistan) has issued Islamic Banking regulation for enhancing Islamic banking in the country to attract more people to start using banking services and this regulation is founded on Bahrain based accounting organization for Islamic Banking which is one of the most famous and accepted organizations in the world. Besides, some banks have opened the Islamic Banking window like Ghazanfar 
Bank, Afghan United Bank, and Afghanistan International Bank (Maierbrugger, 2018).

Following the importance and need of the Islamic banking system in Afghanistan, Da Afghanistan Bank has issued a license for the first time to the first full-fledged Islamic Bank in Afghanistan in April 2018 the bank will continue its operation according to Islamic principles of free interest. Islamic Bank of Afghanistan had AFN (Afghani Currency) 25 million paid-up capital (\$355) and held deposits of $\$ 187$ million (Maierbrugger, 2018). "A successful Islamic bank can be a good sample to encourage the businesses to use the banking sector and build public confidence in the banking sector in Afghanistan it can increase investment in the country which will lead to higher employment and economic growth and development. Islamic banking could absorb billions to the banking sector and provide different opportunities to Afghans and government" said Alam Khan Hamdard, Sukuk adviser to the Finance Ministry of Afghanistan (Maierbrugger, 2018).

Islamic Banking was firstly introduced in the year 2005 where Bank Alfalah, a foreign bank in Afghanistan obtained its' license to carry out Islamic Banking activities. Currently, there are six (6) Islamic Banking windows and one full-fledged Islamic bank in Afghanistan. As per the financial sector financial statistics report for the 4th Quarter, 2017 of Da Afghanistan Bank, the size of the total assets of the banking sector in Afghanistan is AFN 316,349 million ( $\$ 4$ billion), total deposits are AFN 270,153 million ( $\$ 3.5$ billion), the total number of depositors are 3,396,618 and the total number of banks branches are 416 where 130 belong to state-owned banks and 281 are of private banks and 5 are branches of foreign banks (Islamic Bank of Afghanistan, 2019).

IBA was provided license by DAB in 2009 and it is owned by Azizi Hotak Group and it is a 100\% subsidiary of Azizi Bank. IBA has 59 branches across the country and with 800 trained employees (Vizcaino, 2018). Islamic bank of Afghanistan is providing Islamic banking services under four main sections as follow:

In accounts there are Qard al Hasana which is counted as a current account, Mudaraba which is counted as a saving account and last is Mudarabah which is counted as a fixed account. In Banking services, IBA provides ATM and SMS alerts services, Cash management, Remittance, Internet and mobile banking, Payroll.

In Special Islamic Products: IBA is providing Istisna, Salam, Murabaha, Ijarah, Musharaka. In Treasury: IBA is providing Sharia Compliant Foreign Exchange Services Market Services, Sukuk Portfolio Management, Sharia Compliant Money (Islamic Bank of Afghanistan, 2019).

\section{B. Empirical Literature}

There is no article related to the financial ratio analysis of traditional banks which are converted to the Islamic banking system in Afghanistan although limited articles in similar cases are available that we elaborated below;

Islamic banking held courtesy of most people because of its resilience to the economic and banking crises in 2008 (Mohamed, 2016, pp. 74-87). A paper 
done in Malaysia regarding the operation of Islamic banks resulted that the efficiency factors have a direct relationship between the profitability of Islamic Banks (Sufian, 2007, pp. 174-192). In a comparative study between Conventional and Islamic Banks in Pakistan from 2015 to 2017 by using financial ratios to measure the financial performance of Meezan Bank and Faysal Bank to see which of these banks are more profitable than the other. The result shows that their performance was similar in profitability, for instance, the Islamic Bank of Meezan has a superior ROE and EPS (Earning per share) on the other hand the Faysal conventional Bank has a better ROA \& PM (Profit Margin) (Abideen, 2019, pp. 50-72). (Viverita, 2010) In an article completed in Indonesia for the financial analysis of Traditional and Islamic banks comparative analysis during the year, 2006 to 2010 evaluating the effectiveness and efficiency of those banks showed the superiority of Islamic Banking over the Traditional Banking system in profit and revenue. In a research paper conducted in Pakistan on 8 banks from 2007 to 2011 using 6 financial ratios resulted in less efficiency of Islamic Banks in cost management but great achievements in providing less risky loans compared to Traditional Banks while in profitability both were similar and the overall Islamic banks' performance was acceptable and pleasing (Sehrish, 2012). A research paper that examines the financial performance of Islamic banks and Traditional banks throughout the latest financial crisis resulted that on average that on average Islamic banks are stronger resilient in the global financial crisis than Traditional banks (Hasan, 2010). In a study that comparatively examines the financial performance of Islamic and Traditional banks before and after the 2008 financial crisis. The result shows that there is a major difference between Islamic Banks and Traditional Banks in 2007 and 2009, though there is no difference in 2008. Besides the study shows that the crisis hit the Islamic and Traditional banking system the same, but in 2007 Islamic banks outperform than Traditional banks, while in 2009 the Traditional banks perform better (Rashwan, 2010). In a comparative financial analysis case study of traditional and Islamic banks in Malaysia that has performed the financial ratio analysis of 8 Traditional banks and one Islamic Bank (Bank Islam Malaysia Berhad), the result shows that Islamic banks are less risky and more liquid compared to Traditional banks and there are no changes in economic participation between them besides the main reason behind slow growth of Islamic banks is the lack of knowledge of bankers (Samad, A. et al. \&., 1999, pp. 1-14). A study that was conducted to compare the financial performance of Islamic and Conventional banks in Pakistan from 2006 to 2009 by using 18 financial ratios and ANOVA test. The result describes that Islamic banks demonstrated to be less risky, more liquid, and operationally efficient than conventional banks (Ansari, 2010).

On the other hand, in a research paper performed to find out the performance efficiency between Islamic and Traditional Banks in Jordan, Iraq, Bahrain, Turkey, Sudan, Emirates, Egypt, Pakistan, Bangladesh, Sudan, Kuwait, Qatar, and Saudi Arabia from 2009 to 2014 including 66 banks by using Financial ratio measurement method and ANOVA test. The result of this research finds out that the traditional banking system is more efficient and showed a good result in 
case of expenses, profit, and revenue compared to the Islamic banking system but in the case of Islamic banking system ROA and ROE are better than traditional banks. Although the overall result indicates that Islamic Banking is a new system and traditional banking is relatively better than the Islamic Banking system (Mohamed, 2016, pp. 74-87). In an article using 6 financial ratios for comparison between Islamic and Traditional Banking system resulted that Islamic banks were better in profit generation though in cost management Islamic banks were not efficient thus the overall efficiency of Traditional banks were superior (Johnes, 2014, pp. 1-18). In another research paper performed in Islamic and traditional banking analysis in Oman demonstrate that the bank's performance is not a direct result of its capital, deposit, and credit to customers (Tahir, 2010, pp. 78-83). (Samad A. , 2004) In a research performed on 9 Islamic and traditional banks in Bahrain by using financial ratios, analysis showed that Islamic banks showed dominance in case of providing loan but didn't show dominance in case of profitability and liquidity. In a case study of 5 conventional banks (Habib Bank Limited, United Bank Limited, Muslim Commercial Bank Limited, Allied Bank Limited, and Askari Bank Limited) and 5 Islamic banks (Dubai Islamic Bank Limited, Burj Bank Limited, Al Baraka Islamic Bank, Bank Islami Limited and Meezan Islamic Bank) in Pakistan during 2006 to 2015 to find the superior financial performance, between these banks in relationships of risk, liquidity, capital, profitability, and efficiency. Both the quantitative (secondary) data from financial statements and qualitative (primary) data from interviews were used in this research the result designates that Islamic banks are less profitable, less efficient, less risky and more liquid besides there was no difference in terms of capital between both banking system (Khan T. A., 2018, pp. 1-12). In a case study of the comparative study of Malaysian Islamic and Traditional banks from the period of 2007 to 2011 while the data is taken from Bank Negara Malaysia (Central Bank of Malaysia) to find out what are the significant differences among these banks in the aspect of risks, liquidity and profitability performance. The result of this analysis shows that Islamic banks are less profitable and more liquid and less risky compare to Traditional banks (Hazzi, February, 2013). In a comparative case study of Islamic and Traditional banks in Pakistan that find out which of these banks are efficient than the other. The result shows that Traditional banks are more effective than Islamic banks and the reason behind that was high operation cost and management inefficiency (Ashraf, 2011). In a research paper performed in Bangladesh examining the comparative analysis of 19 conventional banks and 6 Islamic banks for a period of 5 years, 2009 to 2013to find out which of these banks are better in making a profit. The result shows that both of these banks have a decreasing profit for the period and they have the same profit without significant difference (Rahaman, 2015).

\section{RESEARCH METHODOLOGY AND DATA SOURCES:}

In this study, the financial performance of the Islamic Bank of Afghanistan is measured as major earnings on assets and equities and other key financial ratios that are the exclusively reliable method for measurement of banks' financial 
performance through financial ratio analysis method. Therefore, in this section the specification of the method and data regarding financial performance analysis is elaborated as below;

We have used secondary data in our research paper and it is taken from IBAs' website that includes financial statements' of IBA such as balance sheet, income statement, and cash flow statement from 2009 to 2019 (Islamic Bank of Afghanistan, 2019).

Financial ratio analysis of financial statements of IBA are performed in two forms; Before Bakhtar bank conversion to an Islamic bank and after conversion to Islamic Bank. The tables and graph 5 show the financial analysis of Bank before conversion to Islamic Bank from 2009-2019 and other tables and graphs from 1 to 4 are showing the financial performance of the Bank after conversion to Islamic Bank from $3^{\text {rd }}$ quarter 2018 to $4^{\text {th }}$ quarter 2019 had been conducted.

As we can see that there is a very limited period that Bakhtar Bank has converted to the Islamic Bank of Afghanistan, so it's considered as our article's assumption and limitation.

\section{A. Research Methodology:}

The financial performance of IBA is measured by using a financial ratio analysis method that contains Return On Assets (ROA), Return On Equities (ROE), Leverage Ratio, and Liquidity ratios. Financial statement analysis is a tool that tries to recognize the financial strengths and weaknesses of a company by creating a connection between the item's financial statements (Khan A. K., 2017).

\begin{tabular}{|c|c|c|c|c|}
\hline \multicolumn{5}{|c|}{ Financial Ratios } \\
\hline No & Ratio & \multirow{2}{*}{\multicolumn{2}{|c|}{$\begin{array}{l}\text { Definition } \\
\text { It is obtained by dividing the totality of current assets } \\
\text { by the totality of current liabilities. Which expresses } \\
\text { companies' ability for facing short term obligations. }\end{array}$}} & Formula \\
\hline 1 & $\begin{array}{l}\text { Current } \\
\text { Ratio }\end{array}$ & & & $\mathrm{CR}=\mathrm{TCA} / \mathrm{TCL}$ \\
\hline \multirow[t]{2}{*}{2} & \multirow[t]{2}{*}{$\begin{array}{l}\text { Leverage } \\
\text { Ratio }\end{array}$} & \multirow{2}{*}{$\begin{array}{l}\text { It evaluates the } \\
\text { capability of a } \\
\text { company to } \\
\text { encounter its } \\
\text { financial } \\
\text { commitments. }\end{array}$} & $\begin{array}{l}\text { Debt to Equity Ratio: It displays } \\
\text { how much of a firm's funding } \\
\text { derives from total debt and total } \\
\text { shareholders' equity. }\end{array}$ & $\begin{array}{l}\text { DTER = Total Debt } \\
\text { /Shareholders Equity }\end{array}$ \\
\hline & & & $\begin{array}{l}\text { Total Outside Liability / Adjusted } \\
\text { Total Net Worth: This is obtained } \\
\text { by dividing total liabilities by total } \\
\text { net worth (Total shares and surplus } \\
\text { reserves) of the company. }\end{array}$ & $\begin{array}{l}\text { TOL/ATNW= Total } \\
\text { liabilities / Total net } \\
\text { worth }\end{array}$ \\
\hline 3 & $\begin{array}{l}\text { Solvency } \\
\text { Ratio }\end{array}$ & \multicolumn{2}{|c|}{$\begin{array}{l}\text { It shows if the company cash flow is enough to pay } \\
\text { long and short term liabilities (loans and interests). }\end{array}$} & $\begin{array}{l}\text { SR }=\text { (Net Income+ } \\
\text { Non-cash expenses) } \\
\text { /Short and Long term } \\
\text { liabilities }\end{array}$ \\
\hline \multirow[t]{2}{*}{4} & \multirow[t]{2}{*}{$\begin{array}{l}\text { Return } \\
\text { Ratios }\end{array}$} & \multirow{2}{*}{$\begin{array}{l}\text { It shows how } \\
\text { efficient a } \\
\text { company is in } \\
\text { making a profit } \\
\text { from the assets } \\
\text { and equities } \\
\text { invested in the } \\
\text { business. }\end{array}$} & $\begin{array}{l}\text { Return on Equity Ratio: This is } \\
\text { obtained by dividing the net profit } \\
\text { by the sum of the owner's equity. }\end{array}$ & $\begin{array}{l}\text { ROER }=\text { Net } \\
\text { Profit*100/Total } \\
\text { shareholders' equity }\end{array}$ \\
\hline & & & $\begin{array}{l}\text { Return on Asset Ratio: Is gained by } \\
\text { dividing the net profit by the sum } \\
\text { of Asset. }\end{array}$ & $\begin{array}{l}\text { ROA }=\text { Net } \\
\text { profit*100/Total asset }\end{array}$ \\
\hline
\end{tabular}


Table 1. Reference (Khan A. K., 2017).

\section{FINDINGS}

Based on the above financial ratio analyses method, formulas, and data taken from IBA financial statements below tables and graphs are generated to express the financial performance of IBA.

All below tables and graphs are the authors' work.

Table 2 and Graph 1 Liquidity Ratio

\begin{tabular}{|c|c|}
\hline \multicolumn{2}{|c|}{ Liquidity Ratio } \\
\hline Date & Current Ratio \\
\hline 3rd QTR 2018 & 1.26708 \\
\hline 4th QTR 2018 & 1.23379 \\
\hline 1st QTR 2019 & 1.32334 \\
\hline 2nd QTR 2019 & 1.76817 \\
\hline 3rd QTR 2019 & 1.98464 \\
\hline 4th QTR 2019 & 1.69851 \\
\hline
\end{tabular}

Liquidity Ratio (Current Ratio)

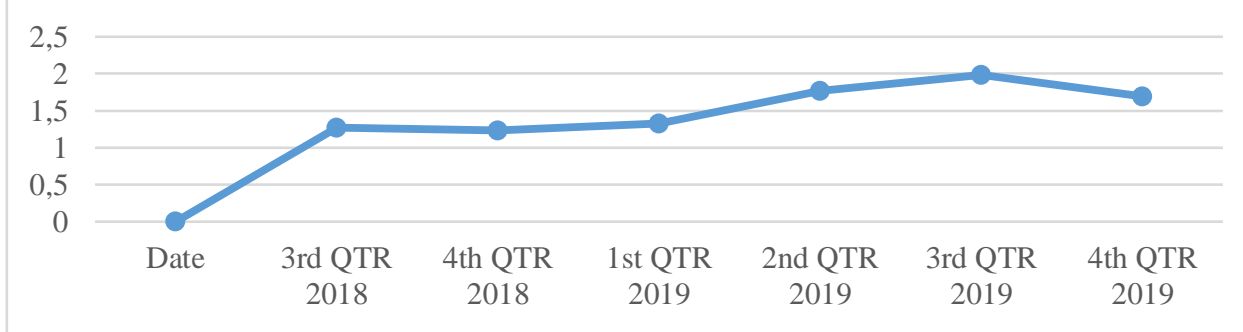

\section{A. Finding:}

(Sing, 2014) suggested that higher current ratio is not a good sign for banks because it shows that banks are more liquid and they are not using their resources efficiently and suggests that the ideal current ratio is between 1 to 1.33 , as a result, IBA has been maintaining a liquidity ratio of a little bit higher than standard although it is satisfactory.

Table 3 and Graph 2: Leverage Ratio

\begin{tabular}{|c|c|c|}
\hline & \multicolumn{2}{|c|}{ Leverage Ratio } \\
\hline Date & Debt to Equity Ratio & Total Outside Liability /Adjusted Net Worth \\
\hline 3rd QTR 2018 & 0.28363 & 6.79324 \\
\hline 4th QTR 2018 & 0.28613 & 9.33269 \\
\hline 1st QTR 2019 & 0.25298 & 7.04693 \\
\hline 2nd QTR 2019 & 0.44569 & 6.25194 \\
\hline 3rd QTR 2019 & 0.47631 & 5.79196 \\
\hline 4th QTR 2019 & 0.53219 & 8.32614 \\
\hline
\end{tabular}


Erdal Arslan \& Ali Bora \& Abdul Hasib Amanat / Comparative Analysis of Conventional and Islamic Banking: The Case of Bakhtar Bank Transforming into Islamic Bank of Afghanistan

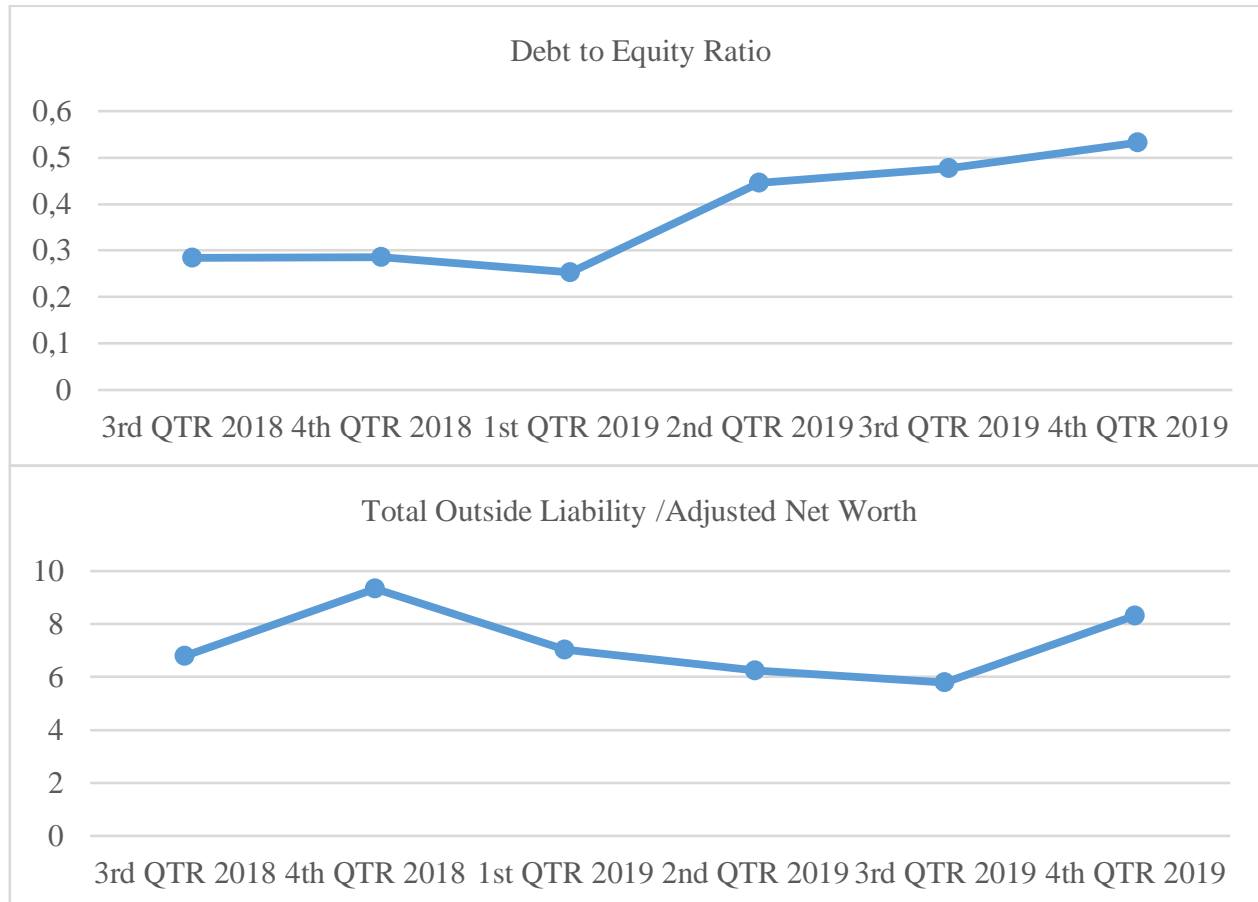

\section{B. Finding}

(Tyre, 2019) expressed that an ideal debt to equity ratio is 1.5 that means how much time debts are to equity as per our analysis of Leverage ratio that contains Debt to equity ratio and TOL/ANW ratio above we can say that It is very obvious that the IBAs' Debt to Equity ratio is deteriorating and having an inverse trend but it's satisfactory because as per Banking law of Afghanistan the bank should maintain regulatory capital for a bank is AFN 1,000,000,000 ( $\$ 13$ million) therefore the bank has always maintained higher amount than required amount by law. Although TOL/ANW ratio has an upward trend which indicates that the bank financial performance is not well it's to mention the ideal TOL/ANW rate is between 1-3 based on Basel international financial standards, which is still acceptable.

Table 4 and graph 3: Solvency Ratio

\begin{tabular}{|c|c|}
\hline \multicolumn{2}{|c|}{ Solvency Ratio } \\
\hline 3rd QTR 2018 & -0.00784 \\
\hline 4th QTR 2018 & -0.00744 \\
\hline 1st QTR 2019 & 0.00386 \\
\hline 2nd QTR 2019 & 0.00714 \\
\hline 3rd QTR 2019 & 0.00246 \\
\hline 4th QTR 2019 & 0.00991 \\
\hline
\end{tabular}




\section{Solvency Ratio}

0,01500

0,01000

0,00500

0,00000

$-0,00500$

\begin{tabular}{|c|c|c|c|c|}
\hline 3rd QTR & th QTR 1st & 2nd QTR & 3rd QTR & 4th QTR \\
\hline 2018 & 2018 & 2019 & 2019 & 2019 \\
\hline
\end{tabular}

$-0,01000$

\section{Finding}

As per the above analysis we can see the trend of solvency ratio which has a positive trend we can express that it is very satisfactory because the ratio has a positive trend in last quarter it is $9 \%$ and it is improving after 4th quarter of 2018, although it is not comparable to international standards which are $6 \%$ to $8 \%$.

Table 5 and graph 4: Return Ratios

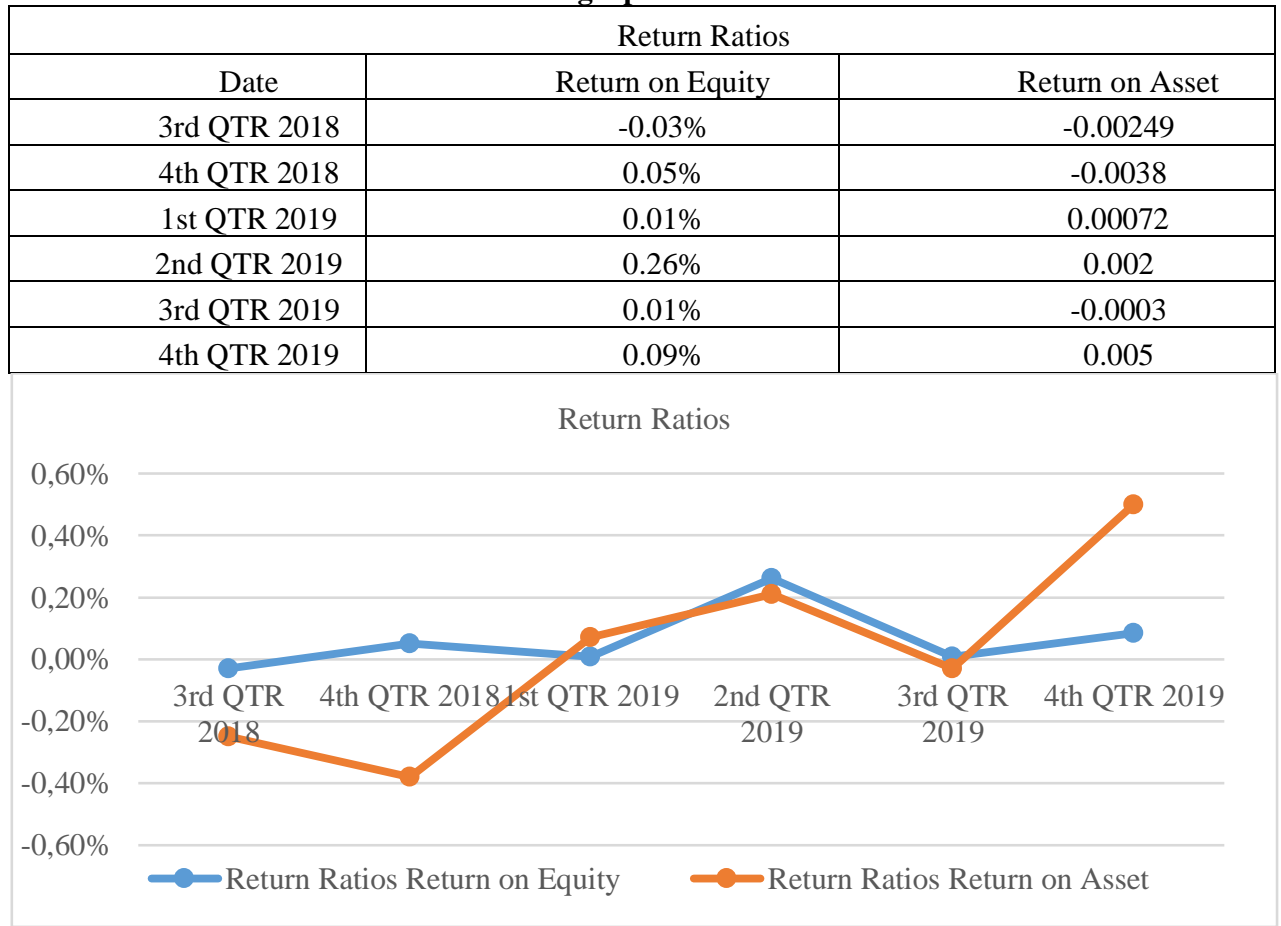

\section{Finding}

ROA and ROE ratios of the bank have a positive upward trend which is satisfactory, especially the return of Asset in the 4th quarter of 2019 is higher than other quarters thus, the bank financial performance is getting better compared to its performance in 2018. 
Erdal Arslan \& Ali Bora \& Abdul Hasib Amanat / Comparative Analysis of Conventional and Islamic Banking:

The Case of Bakhtar Bank Transforming into Islamic Bank of Afghanistan

Table 6 and graph 5: Return on Equity and Return on Asset

\begin{tabular}{|c|c|c|}
\hline Date & Return on Equity & Return on Asset \\
\hline 2009 & $-7.26 \%$ & $-3.75 \%$ \\
\hline 2010 & $-16 \%$ & $-2.80 \%$ \\
\hline 2011 & $3.63 \%$ & $0.66 \%$ \\
\hline 2012 & $2.60 \%$ & $0.60 \%$ \\
\hline 2013 & $1.82 \%$ & $0.29 \%$ \\
\hline 2014 & $1.40 \%$ & $0.17 \%$ \\
\hline 2015 & $-22 \%$ & $-1.59 \%$ \\
\hline 2016 & $-1.97 \%$ & $-1.87 \%$ \\
\hline 2017 & $5.79 \%$ & $0.45 \%$ \\
\hline 2018 & $0.05 \%$ & $-0.58 \%$ \\
\hline 2019 & $0.09 \%$ & $0.50 \%$ \\
\hline
\end{tabular}

Return Ratios

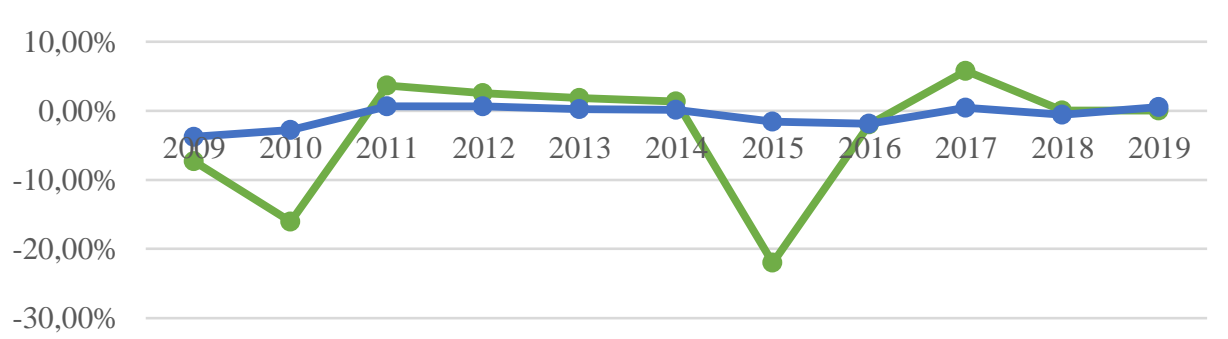

$\longrightarrow$ Return on Equity $\longrightarrow$ Return on Asset

E. Findings: Total ROE and ROA ratio: As we see ROE ratio analysis from 2009 to 2019 the bank has so much up and downtrends in both Return on Equity and Return on Asset but from the time bank has converted to the Islamic banking system (mid-2018) we can see that bank has an upper positive trend in both Return On Equity and Return On Asset, therefore, we can say that financial performance of IBA in ROA and ROE is satisfactory.

\section{CONCLUSION AND RECOMMENDATIONS:}

After performing the financial analysis of IBA through financial ratio analysis method for the period of 2009 to 2019 and after conversion to the Islamic banking system from $3^{\text {rd }}$ quarter 2018 to $4^{\text {th }}$ quarter of 2019 . The result of our analysis and findings shows that IBA financial performance in liquidity ratio, Solvency ratio and returns ratios (ROA and ROE) has improved although Solvency ratio has not improved significantly as a whole we have concluded the bank financial situation and performance satisfactory and acceptable and reject the null hypothesis and accept the alternative hypothesis.

Based on the financial analysis of IBA we have suggested some recommendations for improvement in banks financial performance;

Since the establishment of Bakhtar bank and even after conversion to an Islamic bank, there is always a problem in return ratios of the bank although after 490 
conversion to Islamic banks it has slightly increased. Therefore, the management of IBA should focus on making a comprehensive strategic plan and reform its policies regarding credit policy, marketing policy, and others that can essentially change the performance of the bank.

For increasing banks' profitability, they can emphasize three aspects. First by providing easy loans for businesses or individuals or the bank can invest in local and international Islamic banking products that can bring a huge return to the bank. Secondly, there is a lack of expertise in Islamic banking in the world compared to traditional banking, which leads to inefficiencies and higher liquidity in Islamic banks. Therefore, it is suggested that IBA should emphasize on providing special pieces of training for its employees that can lead to customers' awareness and satisfaction from IBA and attracting more customers that could increase return ratios of the bank. Thirdly as we know the competition is increasing daily for the purpose of gaining a comparative advantage over other banks. IBA needs to hire highly professional staff and adopt new technologies such as ATMs, Internet and Mobile banking that is widely used in banking around the world, this could decrease the operational cost of the bank and increase efficiency in the bank which will result in increasing bank's profit.

In case the current management of the bank is unable to increase the performance of the bank significantly then it's suggested that the chief/managerial staff of the bank should be replaced with highly professional and skillful employees that could bring a positive change in the overall performance of the bank.

\section{REFERENCES}

State Bank of Pakistan Islamic Banking Department. (2013). Islamic Banking Bulletin: Islamic Finance News Pakistan Roadshow. Karachi, Pakistan: State Bank of Pakistan.

Abdus Samad, N. D. (2005). Islamic Banking and Finance. The Experience of Malaysia and Bahrain. Abideen, Z. A. (2019). Financial Performance Analysis of Islamic Bank Aand Conventional Bank in Pakistan 2015-2017- A Comparative Study. https://www.researchgate.net/publication/ 331089587.

Addawe, S. A. (2012). What are the impacts of the global financial crisis on Islamic Banking system and how Islamic Bank spared from the Crisis? Master's Thesis.

Allen N. Berger, C. H. (2016). www.sciencedirect.com. Retrieved from www.sciencedirect.com: https://www.sciencedirect.com/topics/economics-econometrics-and-finance/commercialbanks

Ansari, S. R. (2010). Financial Performance of Islamic and Conventional Banks in Pakistan: A Comparative Study. 8th International Conference on Islamic Economics and Finance.

Anwar. (2010). www.sbp.org.pk. Retrieved from http://www.sbp.org.pk/ibd/Bulletin/2013/IBBJune-2013.pdf

Ashraf, M. M. (2011). The Performance Analysis of Islamic and Conventional Banks: The Pakistan's Perspective. Journal of Money, Investment and Banking, 99-113.

Association, A. $\quad$ B. (2018). www.aba.org.af. Retrieved from https://www.aba.org.af/tablecontentdetails.php?lang=en\&details=profile\&content=Islamic $\% 20$ Bank\%20of\%20Afghanistan

Austen V United States National Bank, 174 US 125 (United States Supreme Court, 1899). Retrieved from: http://www.altlaw.org/

Chachi, A. (2005). https://www.researchgate.net/. Retrieved from https://www.researchgate.net/publication/237696428_Origin_and_Development_of_Com mercial_and_Islamic_Banking_Operations 
Erdal Arslan \& Ali Bora \& Abdul Hasib Amanat / Comparative Analysis of Conventional and Islamic Banking: The Case of Bakhtar Bank Transforming into Islamic Bank of Afghanistan

Chachi, A. (2005). Origin and development of Commercial and Islamic Banking Operations. Journal of King Abdulaziz University Islamic Economic.

DAB. (2017). Monthly Report. Kabul: Da Afghanistan Bank (Central Bank of Afghanistan).

Domat, C. (2019, 12 02). Global Finance. Retrieved from What Is Islamic Finance and How Does It Work? https://www.gfmag.com/topics/blogs/islamic-finance-faq-what-islamic-financeand-how-does-it-work

Hasan, M. \&. (2010). The Effects of the Global Crisis on Islamic and Conventional Banks: A Comparative Study. (Working Paper No.10/201), International Monetary Fund, Washington, DC: U.S. Retrieved November 26, 2012, from: http://www.imf.org/external/pubs/ft/wp/2010/wp10201.pdf.

Hazzi, O. A. (February, 2013). The Financial Performance Analysis of Islamic and Traditional Banks: Evidence from Malaysia. European Journal of Economics, Finance and Administrative Sciences.

IMF. (2007, Feb). imf.org. Retrieved from https://www.imf.org: https://www.imf.org/external/themes/islamicfinance/

International Business \& Economics Research Journal. (2015). A Review of the Literature of Islamic Finance.

Islamic Bank of Afghanistan. (2019, November 10). Islamic Bank of Afghanistan. Retrieved from Investor Relationship: http://www.ibafg.com/home

Islamic Financial Services Industry, I. (2018). Stability Report. Ifsi.

Johnes, J. (2014). Efficiency in Islamic and Traditional Banks. Lancaster University, UK.

Khan, A. K. (2017). Analysis of Financial Statements. Karachi: University of Karachi.

Khan, T. A. (2018). An Investigation of the Performance of Islamic and Interest Based Banking Evidence from Pakistan. HOLISTICA Vol 9, 81-112.

Ladin, M. \&. (2013). Journal of Islamic Finance. The Foundations of Islamic Finance and the Maqāșid Al-Sharī'ah Requirements.

Lukosiunas, R. (2017, November 14). https://greyhouse.weissratings.com. Retrieved from https://greyhouse.weissratings.com/ROA-ROE-and-What-These-Key-Measures-Meanfor-YOUR-Bank

Maierbrugger, A. (2018, 01). Gulf Times. Retrieved from www.gulf-times.com: https://www.gulftimes.com/story/591147/Islamic-finance-in-Afghanistan-a-big-step-towards-

Mastoor, S. (2014). Islamic banking system in Afghanistan. International Academic Conference, (210). Vienna.

Mirakhor, N. M. (2015). Risk Sharing and Shared Prosperity in Islamic Finance. Risk Sharing and Shared Prosperity in Islamic Finance.

Mohamed, R. \&. (2016). Comparative Efficiency Study between Islamic and Traditional Banks. Journal of Finance and Economics, 74-87.

OXFAM International. (2014). Working for Few. OXFAM International, 1-20.

Pettinger, T. (2017, June 28). www.economicshelp.org. Retrieved from https://www.economicshelp.org/blog/glossary/banks/

Rahaman, M. (2015). Are the Islamic Banks Earning more in Bangladesh? ASA University Review.

Rashwan, M. H. (2010). A Comparison between Islamic and Traditional Banks: Pre and Post the 2008 Financial Crisis. http://ssrn.com/abstract=1724451 or http://dx.doi.org/10.2139/ssrn.1724451.

Samad, A. \&. (1999). The Performance of Malaysian Islamic Bank During 1984-1997: An Exploratory Study. International Journal of Islamic Financial Services, 1-14.

Samad, A. (2004). Bahrain Commercial Bank's Performance during 1994-2001. Credit and Financial Management Review 10.

Sehrish, S. S. (2012). Financial Performance analysis of Islamic Banks and conventional banks in Pakistan. Interdisciplinary Journal of Contemporary Research, 186-200.

Sing, R. (2014, Dec 14). www.bankexamstoday.com Retrieved from Financial Ratios with Explanation: https://www.bankexamstoday.com/2014/12/financial-ratios-withexplanation-part-1.html 
Sufian, F. (2007). The Efficiency of Islamic Banking Industry in Malaysia. Journal of Economics \&Finance, 174-192.

Tahir, M. H. (2010). Cost and profit efficiency of Islamic Banks: International evidence using the stochastic frontier approach. Bank and Banking system, 78-83.

Tyre, D. (2019, October 04). https://blog.hubspot.com. Retrieved from Debt to Equity Ratio, Demystified: https://blog.hubspot.com/sales/debt-equity-ratio

Viverita, D. (2010). Performance Analysis of Indonesian Islamic and Traditional Banks. http://ssrn.com/abstract=1868938.

Vizcaino, B. (2018, April 23). www.reuters.com. Retrieved from www.reuters.com: https://www.reuters.com/article/us-islamic-finance-afghanistan/afghanistan-approves-firstfull-fledged-islamic-bank-idUSKBN1HU03U 